\title{
CIPTA KARYA SENI TARI ANAK SEKOLAH DASAR BERPIJAK PADA PERMAINAN TRADISIONAL
}

\author{
Ayu Titis Rukmana Sari' ${ }^{1}$, Wahyudi \\ ayutitis@unpkediri.ac.id ${ }^{1}$,wahyudi@unpkdr.ac.id ${ }^{2}$ \\ Pendidikan Guru Sekolah Dasar, Fakultas Keguruan Ilmu Pendidikan, \\ Universitas Nusantara PGRI Kediri ${ }^{1,2}$
}

\begin{abstract}
Abstrak: Penelitian ini merupakan penelitian pengembangan cipta karya seni tari anak berbasis permainan tradisional yang didalam proses penciptaannya melalui beberapa tahapan yaitu: Tahap Observasi, Eksplorasi, Improvisasi dan Komposisi untuk mencapai kualitas yang maksimal. Nilai kebaharuan pada penciptaan karya tari ini adalah gagasan tentang permainan tradisional yang diangkat pada sebuah pertunjukan karya tari garapan baru untuk anak yang duduk dibangku Sekolah Dasar dengan harapan menarik minat anak agar lebih menggemari permainan tradisional yang merupakan salah satu kekayaan daerah dan memiliki nilai pembelajaran karakter. Permainan tradisional yang menjadi sumber pijakan karya tari ini adalah petak umpet/Obak Dhelik (dalam bahasa Jawa). Penilaian originalitas, kebaharuan dan keterterapan karya dinilai oleh dua validasi ahli tari yang dapat mempertanggungjawabkan penilaian yang diberikan. Karya tari Dhelikan dapat diapresiasi pada link youtube: https://www.youtube.com/watch?v=Y2M-KacYfpw.
\end{abstract}

Kata kunci: cipta karya seni tari, anak sekolah dasar, permainan tradisional.

\section{COPYRIGHT OF ELEMENTARY SCHOOL CHILDREN'S DANCE ARTS BASED ON TRADITIONAL GAMES}

\begin{abstract}
This study is a study of children's dance artwork development based on traditional games which in the creation process is done through several stages, namely: Observation Stage, Exploration Improvement and Composition in order to reach the maximum quality. The novelty value of this dance creation is an idea about traditional games which is carried out at a performance of new dance creation for children in Elementary Schools, expecting that this can attract children's interest to be more fond of traditional games which is one of locality wealth and have character learning. The traditional games become the source of this creation is Hide and Seek/Obak Dhelik (in Javanese). Originality assessment, novelty, and applicability of the creation are assessed by two dance experts which can be responsible in giving the assessment. Dhelikan dance work is able to be appreciated on youtube link: https://www.youtube.com/watch? $v=Y 2 M-K a c Y f p w$.
\end{abstract}

Keywords: dance artwork creation, children of elementary schools, traditional games. 
Ayu, Wahyudi. Cipta Karya Seni Tari...

PENDAHULUAN

Tahap perkembangan anak untuk menjadi generasi penerus berkualitas wajib diasah sejak dini. Menurut Lestariningrum bahwa cara yang paling dekat dengan fase perkembangan anak untuk memahami dunianya adalah melalui bermain yang menyenangkan dapat tepenuhi rasa ingin tahu anak terhadap sesuatu (Lestariningrum, 2018:1). Dengan bermain anak dapat belajar bersosialisasi dengan temannya, mengembangkan kemampuan motoriknya dengan bergerak, dan mengekspresikan pemikirannya. Bermain itu penting bagi anak, karena bermain merupakan bagian sangat penting dari proses tumbuh kembang anak. Melalui kegiatan bermain anak akan belajar berbagai hal tentang kehidupan sehari-hari. Anak akan mendapatkan pengalaman yang berkaitan dengan lingkungannya, baik lingkungan sosial budaya, lingkungan sosial ekonomi maupun lingkungan fisik atau alam sangat berguna meningkatkan kemampuan berbahasa, berpikir, bersikap, bergaul, berkarya dan sebagainya. Dalam permainan anak mencurahkan perhatian perasaan dan pikiran pada proses bermain serta sifat dan bentuk alat permainannya. Dengan demikin anak-anak akan belajar mengenai dan menjajaki lingkungannya (Lestariningrum, 2018:11). Sehingga anak dalam bermain dapat dikatakan belajar, bereksplorasi hal-hal yang baru dengan teman-temannya.

Perkembangan teknologi berdampak penting bagi dunia pendidikan, terutama permainan anak. Seperti diungkap Johan Huizinga (1990) dalam Murtiningsih manusia adalah homo ludens, manusia yang bermain. Dalam permainan, manusia mengenali dunianya, dan menjadikan permainan sebagai media pedagogik yang efektif untuk transfer nilai, selain transfer pengetahuan. Permainan anak modern berbasis teknologi membawa persoalan pedagogik, di samping pengaruh positif dan negatif (Murtiningsih, 2012). Perkembangan teknologi informasi mulai menggeser keberadaan permainan tradisional. Sebagai warisan budaya bangsa yang perlu dilestarikan maka permainan tradisional juga harus tetap dikenalkan pada anak sejak usia dini (Lestariningrum, 2018:46). Realita saat ini anak-anak lebih memilih bermain menggunakan gadget, yang memiliki resiko ketergantungan cukup tinggi dan mengurangi aktivitas tubuh untuk bergerak aktif. Berbagai resiko dari gadget untuk anak juga kurang baik seperti efek radiasi, anak menjadi lebih a-sosial, dan agresif. Namun para orang tua saat ini lebih memilih memberikan gadget untuk anak mereka dengan tujuan agar anak tenang (diam) tanpa mempertimbangkan resiko yang akan terjadi di kemudian hari.

Dengan melihat dan mengamati realita yang sering ditemui, peneliti sebagai koregrafer (penata tari) memiliki ide untuk mengangkat permainan tradisional dijadikan 
Ayu, Wahyudi. Cipta Karya Seni Tari...

sumber pijakan dalam sebuah karya tari baru yang sesuai dengan usia anak Sekolah Dasar. Menurut untung mulyono dalam Sugestiyo menyebutkan bahwa lambat laun tari tidak hanya dipandang sebagai seni profane yang menghibur, tari semakin dipandang sebagai media pembentukan karakter anak sejak usia dini.seni tari tidak hanya mengajarkan anak tentang gerakan tari saja. Seni tari dapat dijadikan sebagai media penanaman nilai-nilai kehidupan kepada anak sedini mungkin, juga sebagai sarana untuk merangsang keativitas anak. Adapun tujuan utama memilih permainan tradisional sebagai sumber pijakan adalah agar anak-anak mengenal dan menyukai bahwa permainan tradisional sangat menyengkan dan tidak kuno.

Melalui permainan tradisional diharapkan anak juga mewarisi nilai-nilai budaya bangsa Indonesia terutama lokal genius daerahnya. Permainan tradisional mengandung nilainilai yang pada perkataan lain, melalui permainan tradisional karakter anak terbentuk sedemikian rupa sehingga sesuai dengan kepribadan bangsa Indonesia (Lestariningrum, 2018:46). Sama halnya dengan pendapat Ernawati bahwa Apabila dikaji lebih mendalam lagi, sebenarnya dalam permainan tradisional terdapat atau mengandung unsur-unsur nilai budaya. Kadang unsur-unsur nilai budaya itu tidak terpikirkan oleh kita. Namun sebenarnya apabila kita amati dan rasakan, ternayata dalam permainan tradisional banyak unsur-unsur nilai budaya yang umumnya bersifat positif, sehingga dapat membentuk kepribadian anak untuk menjadi generasi bangsa yag berbudi luhur (Ernawati, 2006)

Tujuan utama pemerintah dalam menggalakkan pendidikan karakter anak dapat diwujudkan dengan pembelajaran yang memuat tentang nilai-nilai budaya (Jawa misalnya) dengan adanya karakter unggah-ungguh. Nilai-nilai budaya ini terdapat pada permainan tradisional, sehingga secara tidak langsung penanaman karakter anak dapat tercapai dengan permainan tradisional. Menurut Lestariningrum, beragam permainan tradisional mengarahkan anak berkembang secara fisik maupun mental, sosial dan emosi, tak mudah menyerah, bereksplorasi, berekspresimen dan menumbuhkan jiwa kepemimpinan. Dalam permainan yang dilakukan oleh anak, semua kegiatan menjadi bagian penting dan strategis yang akan membangun seluruh potensi yang dimiliki anak secara menyeluruh (Lestariningrum, 2018:46)

Permainan tradisional yang memiliki baragam manfaat positif menjadi pijakan peneliti untuk mewujudkan dalam sebuah karya tari anak yang bernilai edukasi dan tidak meninggalkan unsur-unsur pendidikan karakter yang termuat didalmnya. Salah satu permainan tradisional di Jawa yang diangkat oleh peneliti menjadi sebuah karya tari adalah petak umpet/obak dhelik. Permainan obak dhelik pada tempo dulu dilakukan di malam hari 
Ayu, Wahyudi. Cipta Karya Seni Tari...

dengan jumlah lebih dari satu anak. Manfaat dari permainan obak dhelik menurut peneliti adalah untuk mengembangkan kognitif, afektif dan psikomotor. Selain anak-anak senang dapat bermain bersama teman-temannya serta mengenal lebih dekat ada manfaat yang lebih penting yang mereka dapatkan.

Dari penjelasan yang telah dituangkan pada paragraf sebelumnya artikel ini membahas tentang pengembangan proses penciptaan tari anak Sekolah Dasar. Sisi kebaharuan pada karya tari ini adalah dengan melibatkan secara langsung anak dalam proses penciptaan gerak dan tafsir rasa pada setiap gerak yang dilakukan sehingga kreativitas interpretasi setiap anak dapat diungkapkan suatu contoh : saat mereka bermain dengan gembira, ketika kalah menjadi sedih, kelelahan ketika permainan sudah sangat lama. Dari interpretasi yang dituangkan oleh anak-anak dapat dijadikan pijakan dalam membuat gerak dan menuangkan ekspresi. Dari hasil ide yang telah ditemukan tersebut terwujudlah karya tari diberi judul Dhelikan, yang ditarikan oleh 3 anak perempuan kelas 4 dan 5 Sekolah Dasar. Vocabuler gerak bersumber pada gerak-gerak tari Jawa Timuran dan tipe dasar gerak anak dalam bermain agar selain lokal genius kedaerahan nampak, rasa anak-anak juga tidak pudar dalam wujud visualnya. Properti yang digunakan dalam tari dhelikan adalah balok yang terbuat dari sterofoam dan oncor (obor) yang digunakan anak pada jaman dahulu ketika bermain karena belum ada aliran listrik sedangkan fungsi dari balok tersebut adalah untuk sarana bersembunyi (ndhelik), selain itu untuk menambah estetika dalam sajian pertunjukan tari.

\section{METODE PENELITIAN}

\section{Prosedur Penciptaan Karya}

Penelitian ini merupakan pengembangan dari penciptaan karya tari anak yang berbasis pada permainan tradisonal. Lokasi penelitian bertempat di SDN Jombatan 3 Kabupaten Jombang. Dengan jumlah penari 3 anak penari putri yang masih duduk dikelas 4 dan 5 . Penciptaan karya tari Dhelikan ini pada tahapan prosesnya dibagi menjadi beberapa bagian : tahap observasi, tahap eksplorasi, tahap improvisasi dan tahap komposisi.

\section{Tahap Observasi}

Sebelum melalui tahap observasi peneliti mencari ide atau gagasan terdahulu untuk mengembangkan cipta karya tari anak dengan sumber pijakan permainan tradisional. Setelah menemukan ide yang sesuai peneliti mencari sumber-sumber yang terkait dengan permainan 
Ayu, Wahyudi. Cipta Karya Seni Tari...

petak umpet/obak dhelik. Sumber yang didapat oleh peneliti melui buku, artikel dan pengamatan langsung atau rangsang visual terhadap permainan tersebut. Permainan tradisional obak dhelik yang melibatkan banyak personil dalam proses permainannya, sehingga memberikan dampak positif anak-anak lebih ceria dan seru dalam permainannya.. Ada pergerakan yang atraktif dan kreatif yang dilakukan oleh anak-anak. Ada juga suara teriakan-teriakan yang sangat nyaring yang ditimbulkan. Sehingga berbagai model ekspresi senang, ceria, marah, dan terkadang kecewa dalam permainan juga dapat ditimbulkan oleh setiap anak. Banyak sekali beebagai ekspresi, ucapan dan gerak yang dituangkan oleh anakanak dalam bermain

Hasil observasi yang dilakukan oleh peneliti kemudian dituangkan dalam bentuk naskah tertulis sebagai acuan dalam merancang desain gerak, musik, rias dan busana, properti dan artistik.

\section{Tahap Eksplorasi}

Pada tahap ini adalah proses pencarian atau penjelajahan gerak, seperti pendapat jazuli bahwa Eksplorasi atau penjajakan, yaitu proses berfikir, berimajinasi, dan merasakan ketika merespon/menanggapi suatu objek untuk dijadikan bahan dalam berkarya tari. Wujudnya bisa berupa gerak, irama, tema, dan segala sesuatu yang terkait dengan tari. Syarat utama bereksplorasi adalah harus memiliki daya tarik terhadap objek (Jazuli dalam Restiana,dkk : 2019).

Dari tahap observasi (pengamatan) terhadap gerak yang dilakukan oleh anak dalam permainan petak umpet, kemudian distilisasi ke dalam gerak tari tetap dengan mengutamakan alur dinamika setiap bagiannya agar karya tari tidak terkesan monoton. Selain itu, aspek kedaerahan dalam bentuk gerak khas Jawa Timuran juga menjadi pertimbangan dalam garap gerak agar ciri khas kedaerah tetap muncul. Disisi lain usia anak harus menjadi pertimbangan juga karena kemampuan bergerak dari setiap tahapan usia pada anak tidak sama, selain itu psikologi anak dalam bermain juga harus tetap nampak.

\section{Tahap Improvisasi}

Setelah tahap eksplorasi maka dilanjutkan ke tahapan selanjutnya yaitu improvisasi. Tahap imrovisasi sering disebut tahap spontanitas dalam proses berkarya. Ciri spontanitas ini dapat memberikan kekayaan dan variasi pengalaman gerak tanpa harus perencanaan lebih dahulu (Hadi 2011: 77). Pada tahap ini setelah penata tari melakukan eksplorasi dan menentukan 
Ayu, Wahyudi. Cipta Karya Seni Tari...

bahan gerak dasar, penata tari mencoba menemukan bentuk-bentuk baru yang akan menjadi ciri khas penata tari. Penata tari pasti memiliki pengalaman empiris dalam bergerak disinilah terkadang muncul secara spontan dari pengalaman-pengalam yang pernah dialami tanpa ada perencanaan terlebih dahulu. Kemudian disusun langsung saat memulai latihan bersama penari

\section{Tahap Komposisi}

Komposisi merupakan proses menyusun gerak yang telah dihasilkan dari proses eksplorasi, improvisasi. Pada tahap ini termasuk mengevaluasi, menyusun, merangkai, atau menata motif-motif gerak menjadi satu kesatuan yang disebut koreografi (Hadi, 2011: 78-79). Pada tahap komposisi ini penata tari menggabungkan hasil proses yang dilakukan di tahap eksplorasi dan improvisasi sehingga menjadi satu sajian karya tari baru.

\section{Jenis Data dan Subjek Coba}

Penelitian yang berupa pengembangan karya seni atau cipta karya seni ini, dari data yang akan dianalisis adalah originalitas, kebaharuan dan keterterapan karya. Data-data tersebut akan diperolah dari dua orang ahli dengan latar belakang seni tari yaitu Ratih Asmarani, M.Pd. dan Pance Mariati, S.Pd., M.Sn.

\section{Instrumen}

Pada penelitian ini instrumen yang digunakan adalah angket lembar penilaian karya seni. Adapun aspek yang akan diuji adalah originalitas, kebaharuan dan keterterapan karya menggunakan skala Likert. Kisi-kisi kevalidan produk antara lain:

Tabel 1. Kisi-Kisi Kevalidan Produk

\begin{tabular}{|c|}
\hline Indikator \\
\hline Originalitas Karya \\
\hline Kebaruan karya yang disajikan \\
\hline Kesesuaian karya tari dengan judul \\
\hline Keutuhan sajian karya seni tari \\
\hline Kebaharuan Karya \\
\hline Kesesuaian musik tari dengan gerak tari \\
\hline Kesesuaian busana dan rias dengan karya tari \\
\hline Kesesuaian properti tari dengan karya tari \\
\hline Kesesuaian artistik denga karya tari \\
\hline
\end{tabular}


Ayu, Wahyudi. Cipta Karya Seni Tari...

\begin{tabular}{|c|}
\hline Keterterapan Karya \\
\hline Kesesuaian karya tari dengan karakter anak \\
\hline Nilai-nilai moral yang terkandung dalam karya tari \\
\hline Kesesuaian kerumitan karya dengan siswa Sekolah Dasar \\
\hline
\end{tabular}

*Tiap indikator diukur dalam lima skala

\section{Prosedur dan Teknik Analisis Data}

Analisis data pada penelitian ini menggunakan teknik kuantitatif deskriptif, yaitu data berupa skor perolehan dari ahli dan saran aka ditelaah serta dilakukan kajian untuk perbaikan karya tari.

\section{HASIL DAN PEMBAHASAN}

\section{Proses Penciptaan Karya Tari Dhelikan}

\section{Tahap Observasi}

Pada tahap ini dilakukan pengamatan secara langsung pada permainan petak umpet. Pengamatan yang dilakukan adalah pada aspek gerak, pola permainan, jumlah anak yang terlibat dalam permainan, ekspresi masing-masing anak ketika bermain dan waktu serta tempat ketika anak bermain. Hasil pengamatan terhadap permainan tersebut digunakan dalam merancang gerak, ekspresi (penghayatan), properti, artistik, musik tari dan rias busana.

\section{Tahap Eksplorasi}

Tahap ini merupakan pencarian gerak dasar setelah melakukan pengamatan pada permainan petak umpet atau obak dhelik. Dari hasil rangsang visual bentuk permainan tersebut penata tari mengembangkan gerak yang dilakukan oleh pemain, suatu missal: cara pemain bersembunyi, berlari, menentukan siapa yang akan bersembunyi dan yang akan mencari, dan lain sebagainya.

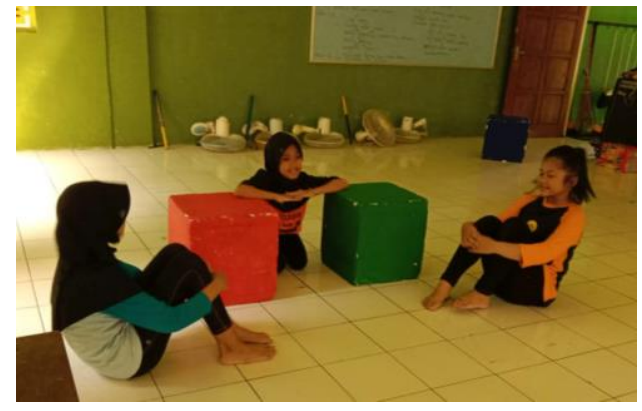

Gambar 1. Foto proses (dok. Endah)

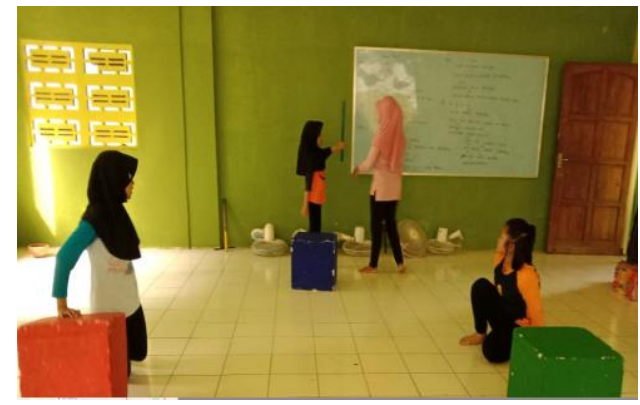

Gambar 2. Foto proses

(dok. Endah) 
Ayu, Wahyudi. Cipta Karya Seni Tari...

\section{Tahap Improvisasi}

Tahap improvisasi lebih pada pemunculan-pemunculan gerak spontanitas penata tari tanpa ada perencanaan sesuai dengan pengalaman bergeraknya. Ciri spontanitas ini dapat memberikan kekayaan dan variasi pengalaman gerak tanpa harus perencanaan lebih dahulu (Hadi 2011: 77). Pada karya tari Dhelikan salah satu contoh gerakan berlari distilisasi / diperhalus agar menjadi gerakan yang indah menjadi srisig dengan pose badan membungkuk dan kedua tangan dibelakang punggung setinggi pinggang.

\section{Tahap Komposisi}

Komposisi merupakan proses menyusun gerak yang telah dihasilkan dari proses eksplorsi, improvisasi. Pada tahap ini termasuk mengevaluasi, menyusun, merangkai, atau menata motif-motif gerak menjadi satu kesatuan yang disebut koreografi (Hadi, 2011: 78-79). Pada tahap ini yaitu penggabungan semua gerak yang telah didapatkan pada tahap eksplorasi dan improvisasi menjadi satu sajian karya tari yang utuh.

Setelah melalui tahapan-tahapan diatas dalam pengolahan gerak tari, selanjutnya dilakukan tahapan dalam proses penciptaan musik tari, properti, artistik atau seting dan tata rias busana.

1) Musik Tari

Musik sebagai pengiring tari dapat dianalisis fungsinya sebagai iringan ritmis gerak tarinya, dan berfungsi sebagai ilustrasi pendukung suasana tema tariannya, atau dapat terjadi kedua fungsinya secara harmonis (Hadi 2011: 28). Musik merupakan nyawa bagi tari sehingga kedudukan musik juga sangat penting dalam penciptaan sebuah karya tari, untuk menghidupkan karya tari sehingga dapat tersampaikan pesan yang dimaksud. Musik tari Dhelikan ini menggunakan seperangkat gamelan Pelog. Pemilihan gamelan dalam instrumen musik untuk mengentalkan rasa lokal genius dan menyesuaikan dengan pola garap dengan sumber pijakan permainan tradisional. Garap musik menyesuaikan dengan gerak pada setiap bagiannya dan juga suasana yang dihadirkan. Pada proses penciptaan musik juga mengutamakan kesesuaian dengan usia anak, sehingga menjadi sajian tari anak yang utuh.

2) Properti 
Ayu, Wahyudi. Cipta Karya Seni Tari...

Properti yang digunakan adalah balok berjumlah 3 yang digunakan anak-anak untuk bersembunyi, selian itu juga dapat dinaiki dan dilempar agar kesan benda mati dapat berfungsi secara total sehingga menambah estetika pada pertunjukan tari. Yang kedua adalah obor digunakan untuk mencari teman-temannya yang bersembunyi karena permainan ini umumnya pada jaan dahulu dilakukan malam hari, sehingga membutuhkan penerangan.

3) Artistik/Setting

Artistik/seting dalam karya tari ini menyesuaikan dengan tema. Permainan petak umpet pada umumnya dilakukan pada malam hari di halaman rumah. Untuk menambah suasana malam hari ditambah dengan obor mengelilingi arena pertunjukan sebagai penerangan dan menambah kesan estetik.

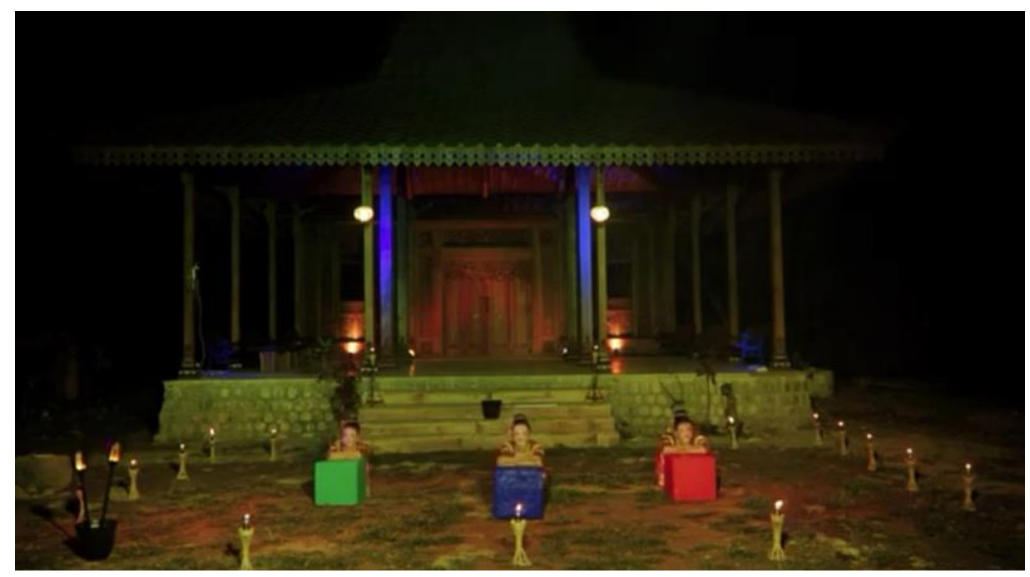

Gambar 3. Seting, Aristik dan Properti

(dok. Endah)

4) Tata Rias dan Busana

Tata rias yang digunakan ialah rias cantik dan sesuai dengan karakter anak. Busana didesain sederhana untuk mempermudah pergerakan anak-anak dalam bergerak aktif. Serta disesuaikan dengan usia dan tema tentang permainan tradisional. 


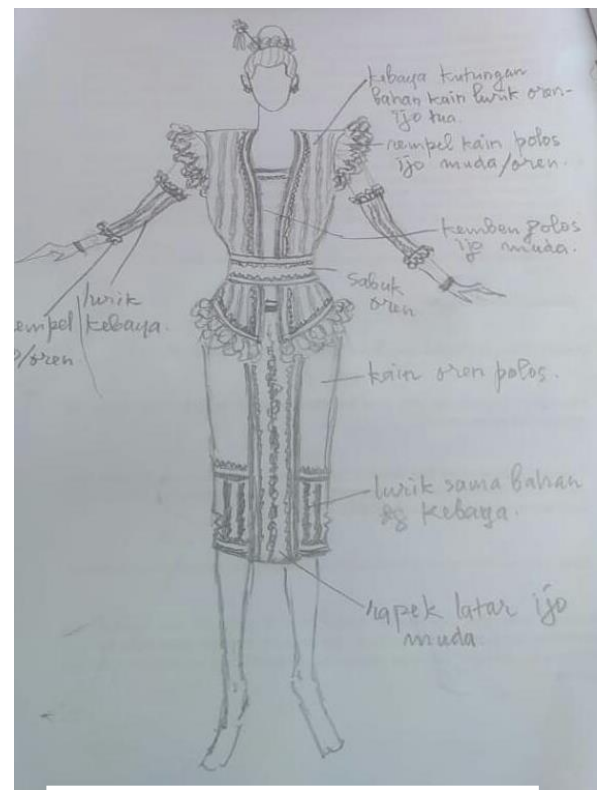

Gambar 4. Desain

busana

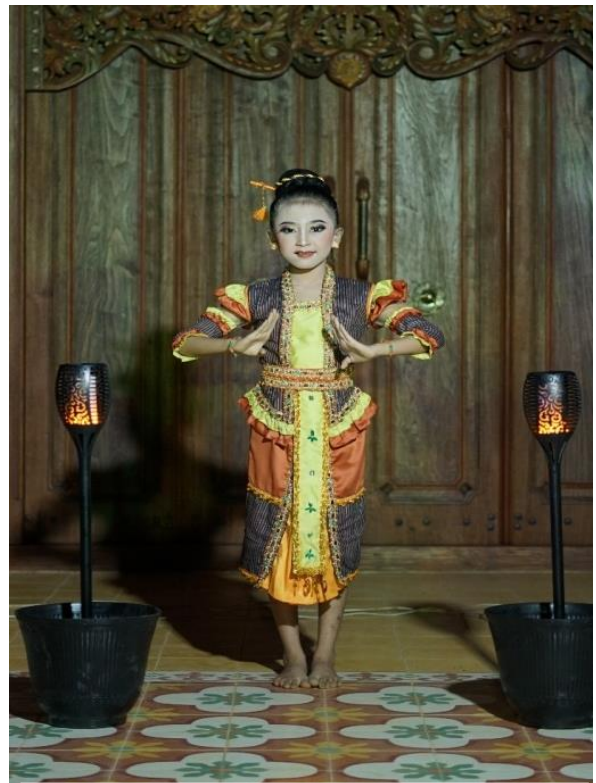

Gambar 5. Rias dan Busana (dok. Endah)

\section{Proses Analisis data}

Validasi ahli dilakukan dua kali oleh ahli tari untuk mencapai kualitas yang maksimal. Validasi yang pertama oleh Ratih Asmarani M.Pd dengan perolehan skor 4,5 yang bearti produk valid dengan revisi kecil diantaranya busana penari perlu disesuaikan, penambahan properti obor. Dilanjutkan validasi kedua dengan perolehan skor 5 yang berarti produk dapat digunakan. Validasi yang kedua oleh Pance Mariati S.Pd., M.Sn. dengan perolehan skor 4,6 yang berarti produk valid dengan revisi kecil, yaitu: Gerak pada bagian awal, beberapa bagian pada pola lantai dipertimbangkan dengan penyususnan gerak. Pada validasi kedua dengan perolehan skor 5 yang berarti produk dapat digunakan.

\section{KESIMPULAN}

Karya tari yang berjudul Dhelikan ini dalam proses penggarapannya melalui beberapa tahap diantaranya; Tahap Observasi, Eksplorasi, Improvisasi dan Komposisi. Karya ini dinyatakan memiliki tingkat originalitas, kebaharuan dan keterterapan yang tinggi dilihat dari hasil validasi kedua ahli tari. Karya tari ini dapat diapresiasi pada link youtube https://www.youtube.com/watch?v=Y2M-KacYfpw.

\section{DAFTAR RUJUKAN}

Ardini, Pupung \& Anik Lestaringrum. 2018. Bermain dan Permainan Anak. Nganjuk: Adji Media Nusantara. 
Ayu, Wahyudi. Cipta Karya Seni Tari...

Hadi, Sumandiyo. 2011. Koreografi (Bentuk-Teknik-Isi). Yogyakarta: Multi Grafindo.

Murtiningsih, RR., Siti. 2012. Pendidikan Multikultural Melalui Dolanan Anak: Studi Tentang Dolanan Anak "Sudamanda" Dalam Perspektif Teori Pendidikan John Dewey. Prosiding Seminar Internasional Multikultural \& Globalisasi. IMG 4 (2), p153-166”, https://multikulturalui.files.wordpress.com/2013/05/prosiding-simg-ui2012-jilid-2-15.pdf.

Purwaningsih, Ernawati. 2006. Permainan Tradisional Anak: Salah Satu Khasanah Budaya yang Perlu Dilestarikan. Jurnal Sejarah dan Budaya Jawa. Jantra 1 (1), p40-46" ,http://repositori.kemdikbud.go.id/5136/1/Jantra_Vol._I_No._1_Juni_2006.pdf.

Restiana, Ida dkk. 2019. Proses Penciptaan Tari Patholan di kabupaten Rembang: Jurnal Seni Tari 8. Unnes 111-119”, http://journal.unnes.ac.id/sju/index.php/jst 